37. Okada K, Tanaka $\mathrm{Y}$, Bernstein $\mathrm{M}$, et al. Pulmonary hemodynamics modify the rat pulmonary artery response to injury. A neointimal model of pulmonary hypertension. Am J Pathol 1997;151:1019-25.

38. Abe K, Toba M, Alzoubi A, et al. Formation of plexiform lesions in experimenta severe pulmonary arterial hypertension. Circulation 2010;121:2747-54.

39. Down JD. The nature and relevance of late lung pathology following localised irradiation of the thorax in mice and rats. Br J Cancer Supp/ 1986;7:330-2.

40. Ward WF, Lin PJ, Wong PS, et al. Radiation pneumonitis in rats and its modification by the angiotensin-converting enzyme inhibitor captopril evaluated by high-resolution computed tomography. Radiat Res 1993;135:81-7.

41. Gillette SM, Powers BE, Orton EC, et al. Early radiation response of the canine heart and lung. Radiat Res 1991;125:34-40.

42. Loyd JE, Bolds JM, Sheller JR, et al. Acute effects of thoracic irradiation on lung function and structure in awake sheep. J Appl Physiol 1987;62:208-18.

43. Guerry-Force ML, Perkett EA, Brigham KL, et al. Early structural changes in sheep lung following thoracic irradiation. Radiat Res 1988;114:138-53.

44. van Albada ME, Bartelds $B$, Wijnberg $H$, et al. Gene expression profile in flowassociated pulmonary arterial hypertension with neointimal lesions. Am J Physiol Lung Cell Mol Physiol 2010;298:L483-91.

45. Rabinovitch M. Pathobiology of pulmonary hypertension. Annu Rev Pathol 2007;2:369-99

46. Sakao S, Tatsumi K, Voelkel NF. Reversible or irreversible remodeling in pulmonary arterial hypertension. Am J Respir Cell Mol Biol 2010;43:629-34.

47. Wagenvoort CA, Mooi WJ. Plexogenic arteriopathy. In: Munro Neville A, Walker F, Gottlieb LS, eds. Biopsy Pathology of the Pulmonary Vasculature. London: Chapman \& Hall Medical, 1989:56-113.

48. Taraseviciene-Stewart L, Kasahara Y, Alger L, et al. Inhibition of the VEGF receptor 2 combined with chronic hypoxia causes cell death-dependent pulmonary endothelial cell proliferation and severe pulmonary hypertension. FASEB J 2001;15:427-38.

49. White RJ, Meoli DF, Swarthout RF, et al. Plexiform-like lesions and increased tissue factor expression in a rat model of severe pulmonary arterial hypertension. Am J Physiol Lung Cell Mol Physiol 2007;293:L583-90.

50. Wagenvoort CA. Open lung biopsies in congenital heart disease for evaluation of pulmonary vascular disease. Predictive value with regard to corrective operability. Histopathology 1985;9:417-36

51. Ivy DD, McMurtry IF, Colvin $\mathrm{K}$, et al. Development of occlusive neointimal lesions in distal pulmonary arteries of endothelin $\mathrm{B}$ receptor-deficient rats: a new model of severe pulmonary arterial hypertension. Circulation 2005;111: 2988-96.

52. Coppes RP, Muijs CT, Faber $\mathrm{H}$, et al. Volume-Dependent expression of in-field and out-of-field effects in the proton-irradiated rat lung. Int $J$ Radiat Oncol Biol Phys 2011:81:262-9.

53. Macario DK, Entersz I, Abboud JP, et al. Inhibition of apoptosis prevents shear-induced detachment of endothelial cells. J Surg Res 2008:147:282-9.

54. Ueno H, Kanellakis P, Agrotis A, et al. Blood flow regulates the development of vascular hypertrophy, smooth muscle cell proliferation, and endothelial cell nitric oxide synthase in hypertension. Hypertension 2000:36:89-96.

55. Schermuly RT, Dony E, Ghofrani HA, et al. Reversal of experimental pulmonary hypertension by PDGF inhibition. J Clin Invest 2005;115:2811-21.

56. Diller GP, Thum T, Wilkins MR, et al. Endothelial progenitor cells in pulmonary arterial hypertension. Trends Cardiovasc Med 2010;20:22-9.

57. Zhao YD, Courtman DW, Deng Y, et al. Rescue of monocrotaline-induced pulmonary arterial hypertension using bone marrow-derived endothelial-like progenitor cells: efficacy of combined cell and eNOS gene therapy in established disease. Circ Res 2005:96:442-50.

\title{
Bronchoalveolar lavage-directed therapy does not affect prevalence of Pseudomonas aeruginosa infection and structural lung injury in children with cystic fibrosis
}

Early Pseudomonas aeruginosa pulmonary infections lead to increased morbidity and mortality in children with cystic fibrosis (CF). As this diagnosis is difficult to ascertain in the nonexpectorating patient, the authors set out to determine if bronchoalveolar lavage (BAL)directed therapy during the first 5 years of life leads to better outcomes than standard practice (which is therapy based on clinical features and oropharyngeal cultures).

This multicentre, randomised, parallel-group trial recruited patients between 1999 and 2005 from eight CF centres in Australia and New Zealand. Of 267 eligible infants, 36\% were excluded. Patients were randomly assigned in a 1:1 ratio to receive either BAL-directed or standard therapy.

Primary outcomes at 5 years were prevalence of $P$ aeruginosa on BAL cultures and total CFCT score, a measure of pulmonary structural damage. Secondary outcomes were $z$ scores for weight, height and body mass index, pulmonary function parameters, CF-CT score components, exacerbation rate, number and duration of hospitalisations for non- $P$ aeruginosa pulmonary infections, number of episodes of $P$ aeruginosa infection per child-year and final BAL microbiology and inflammatory indices.

This study did not find any statistically significant differences between groups for any primary or secondary outcomes, except for a reduced length of hospital stay for non- $P$ aeruginosa respiratory-related admissions in the BAL-directed therapy group. While this may help determine clinical management, it is essential to note that the study was not powered for secondary outcomes, and CF-CT scores have yet to be validated as a clinical outcome measure.

- Wainwright CE, Vidmar S, Armstrong DS, et al; ACFBAL Study Investigators. Effect of bronchoalveolar lavage-directed therapy on Pseudomonas aeruginosa infection and structural lung injury in children with cystic fibrosis: a randomized trial. JAMA 2011:306:163-71.

\section{H Haja Mydin}

Correspondence to Dr Helmy Haja Mydin, Department of Respiratory Medicine, Aberdeen Royal Infirmary, Foresterhill, Aberdeen AB25 2ZN, UK; enidan@doctors.org.uk 